Check for updates

The BMJ

Cite this as: BMJ 2020;371:m4555 http://dx.doi.org/10.1136/bmj.m4555 Published: 23 November 2020

\section{Covid vaccine: GPs need more clarity on logistics and planning, say leaders}

\author{
Gareth lacobucci
}

GPs must not be sidelined in the planning and logistics of how to deliver covid-19 vaccinations around the country, primary care leaders have urged.

Earlier this month the NHS published a draft agreement ${ }^{1}$ to enable general practices to start delivering a covid-19 vaccine from as early as December through local primary care networks (PCNs). Designated sites will be expected to deliver vaccines seven days a week from 8 am to $8 \mathrm{pm}$ if supply allows, and practices will be paid £12.58 (€14.16; \$16.82) per dose.

But the final agreement is yet to be published, and uncertainty persists over which vaccines GPs will administer, what volume of patients they will be expected to vaccinate, and how their sites will link up with the mass vaccination centres the government is setting up around England.

Mass vaccination centres, likely to be run by a single local organisation such as an acute and community health trust, are unlikely to be operational straight away. But England's health secretary, Matt Hancock, told BBC's Today programme on 20 November that training "is under way" to recruit thousands of staff to "one of the biggest civilian projects in history."

\section{Clarity and coordination}

Primary care leaders told The BMJ that GPs were keen to play their part in the national effort, but they highlighted a lack of clarity and coordination over key elements of planning and logistics.

Ruth Rankine, director of the NHS Confederation's PCN, told The BMJ, "There is real frustration among our members at the moment that they're planning their PCN programme, but with no line of sight of what's happening in the wider system. From our perspective, it appears that there is no coordination."

Rankine said that PCNs were not clear about how their local sites would coordinate with mass sites. She asked, "Obviously there are interdependencies between the two, because if a patient is vaccinated at a mass vaccination site, how does their practice know that they've been vaccinated? In terms of the sharing of records, and the call and recall system, how do you know?"

PCNs also wanted more clarity over whether they would be vaccinating people in care homes or whether residents would be seen by mobile testing teams, which the government has promised to roll out, she added.

"It's really difficult to understand the logistics of it all and how it all ties together into a comprehensive programme where everyone is clear what role they are playing,” Rankine explained. She added that GPs were "definitely concerned that too much is being asked of them," particularly with the government's sudden announcement on Friday 20 November that people over 50 in England should ask their GP for a flu vaccination.

"People are already saying that the phones are ringing off the hook," she said.

\section{Notice period}

Joe McManners, a GP in Oxford and clinical director of a PCN, said, "The major issue is that there's so much uncertainty and so much we don't know. We could definitely administer 50 vaccines in a practice in a week. But we probably couldn't do thousands. We don't really know what the ask is, so it is quite difficult to try to recruit people or get people to do extra time. You need to give them a little bit of warning.

"There is definitely a massive good will out there in general practice to make it work. We just need the back-up and support to make sure that the planning and the notice periods [of what is expected] are good."

Tracey Vell, chief executive of Manchester Local Medical Committees, said that the message from a meeting she had attended with local PCN leaders was that "we really want to do this."

But she noted anxieties around certain issues, including what level of staffing PCNs would need and how prescriptive NHS England would be in the enhanced service around things such as the number of vaccination sites allowed in each local area.

She added. "I think we're prepared, but sometimes NHS England is known to throw a curveball. I'm hoping that the reason they are taking their time [to publish more information] is because they're listening first."

1 lacobucci G. Covid-19: GPs to get $£ 12.58$ per dose to deliver vaccine from December. BM/2020;371:m4354. doi: 10.1136/bmi.m4354 pmid: 33172836

This article is made freely available for use in accordance with BMJ's website terms and conditions for the duration of the covid-19 pandemic or until otherwise determined by BM]. You may use, download and print the article for any lawful, non-commercial purpose (including text and data mining) provided that all copyright notices and trade marks are retained. 